\title{
Aortic valve endocarditis associated with LV aneurysm secondary to previous infarct
}

\author{
Umar Imran Hamid, Alastair Graham, Harry Parissis
}

Department of Cardiothoracic Surgery, Royal Victoria Hospital, Belfast, UK

Correspondence to Umar Imran Hamid, umar79@hotmail.com

\section{DESCRIPTION}

Rupture of the free wall of the left ventricle (LV) is a catastrophic complication occurring in $4 \%$ of patients after myocardial infarction (MI) and in $23 \%$ of those who die of MI. ${ }^{1}$

The posterior wall is the frequent location of a false ventricular aneurysm, ${ }^{2}$ because anterior or lateral LV ruptures are unlikely to be contained, resulting in sudden death.

A 69-year-old male patient with a history of previous myocardial infarction presented with worsening breathlessness and fever. On admission, echocardiography was indicative of aortic valve endocarditis with an incidental finding of LV aneurysm. Blood cultures grew Streptococcus viridans. The patient underwent aortic valve replacement, coronary artery bypass graft and plication of the LV aneurysm (figure 1) using teflon strips buttress (figure 2). Postoperative recovery was uneventful with improvement in contractile function.

A thin or disrupted myocardium moves dyskinetically or the cavity can be non-contractile, leading to congestive heart failure or to dangerous ventricular arrhythmia. Stagnant flow may lead to thrombosis or embolic events, thus the mere presence of a thrombus inside the cavity can enable a correct diagnosis of LV aneurysm.

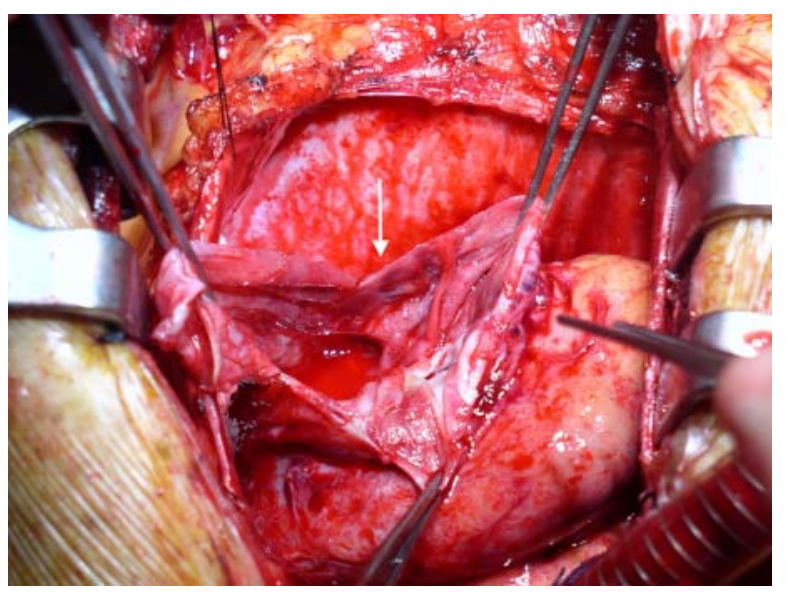

Figure 1 Arrow showing left ventricle aneurysm.

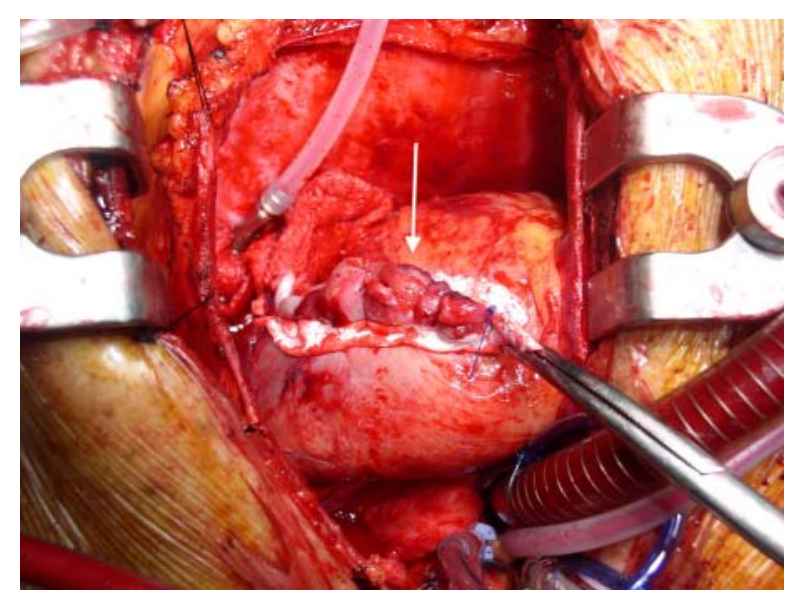

Figure 2. Arrow showing repaired left ventricle aneurysm with teflon strips.

The aim of surgical therapy is to exclude the mass of abnormal myocardium improving wall compliance, reducing filling pressure and bringing about enhanced contractile performance.

\section{Learning points}

- Left ventricle (LV) false aneurysm may have a long insidious course and may only be diagnosed incidentally.

- It is usually formed posteriorly as part of a contained LV rupture due to previous myocardial infarction. The treatment is surgical resection and it is usually a part of a complex operation. The 'neck' of the pseudoaneurysm is usually apparent as a fibrous ring that communicates with the LV.

\section{REFERENCES}

1. Pollak H, Nobis H, Miczoc J. Frequency of left ventricular free wall ruptures complicating acute myocardial infarction since the advent of thrombolysis. Am J Cardiol 1994;74:184-6.

2. Yeo TC, Malouf JF, Oh JK, et al. Clinical profile and outcome in 52 patients with cardiac pseudoaneurysm. Ann Intern Med 1998;128:299-305. 


\section{BMJ Case Reports}

This pdf has been created automatically from the final edited text and images.

Copyright 2012 BMJ Publishing Group. All rights reserved. For permission to reuse any of this content visit http://group.bmj.com/group/rights-licensing/permissions.

BMJ Case Report Fellows may re-use this article for personal use and teaching without any further permission.

Please cite this article as follows (you will need to access the article online to obtain the date of publication).

Imran Hamid U, Graham A, Parissis H. Aortic valve endocarditis associated with LV aneurysm secondary to previous infarct. BMJ Case Reports 2012;10.1136/ bcr-2012-006874, Published XXX

Become a Fellow of BMJ Case Reports today and you can:

- Submit as many cases as you like

- Enjoy fast sympathetic peer review and rapid publication of accepted articles

- Access all the published articles

- Re-use any of the published material for personal use and teaching without further permission

For information on Institutional Fellowships contact consortiasales@bmjgroup.com

Visit casereports.bmj.com for more articles like this and to become a Fellow 